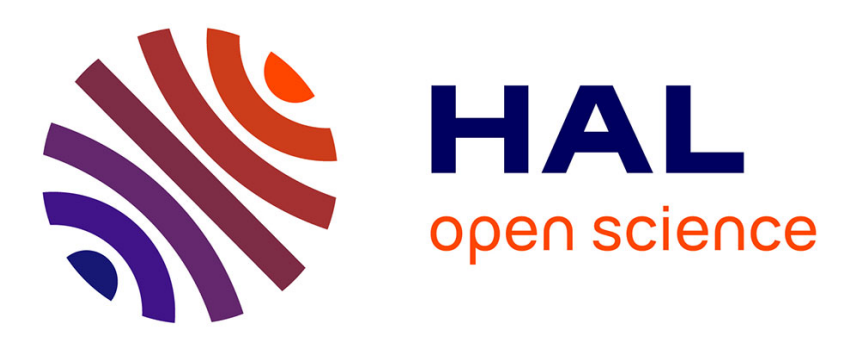

\title{
An Electrophilic Ruthenium Complex that Enables the Cycloisomerization of 1,6-Enynes to Access Azabicyclo[4.1.0]heptenes
}

Rui Liu, Dongfeng Yang, Fengwei Chang, Laurent Giordano, Guohua Liu, Alphonse Tenaglia

\section{To cite this version:}

Rui Liu, Dongfeng Yang, Fengwei Chang, Laurent Giordano, Guohua Liu, et al.. An Electrophilic Ruthenium Complex that Enables the Cycloisomerization of 1,6-Enynes to Access Azabicyclo[4.1.0]heptenes. Asian Journal of Organic Chemistry, 2019, 8 (11), pp.2011-2016. 10.1002/ajoc.201900529 . hal-02514511

\section{HAL Id: hal-02514511 \\ https://hal.science/hal-02514511}

Submitted on 23 Mar 2020

HAL is a multi-disciplinary open access archive for the deposit and dissemination of scientific research documents, whether they are published or not. The documents may come from teaching and research institutions in France or abroad, or from public or private research centers.
L'archive ouverte pluridisciplinaire HAL, est destinée au dépôt et à la diffusion de documents scientifiques de niveau recherche, publiés ou non, émanant des établissements d'enseignement et de recherche français ou étrangers, des laboratoires publics ou privés. 


\title{
An Electrophilic Ruthenium Complex that Enables the Cycloisomerization of 1,6-Enynes to Access Azabicyclo[4.1.0]heptenes
}

\author{
Liu, R., Yang, D. F., Chang, F. W., Giordano, L., Liu, G. H., Tenaglia, A.
}

\begin{abstract}
Cycloisomerization of 1,6-enynes to access azabicyclo[4.1.0]heptenes was achieved in the presence of commercially available $\left[\mathrm{RuCl}_{2}(\mathrm{CO})_{3}\right]_{2}$ after a comprehensive study on the electronic properties of ruthenium complexes. A series of 1,6-enynes bearing an internal/terminal alkyne motif proved to be good candidates for substrates, giving their corresponding bicyclo[4.1.0]heptenes in good to excellent yields. Substitution patterns on either alkyne or alkene have no significant influence on the yields of bicyclic adducts.
\end{abstract}

Cycloisomerization reactions of 1,6-enynes catalyzed by transition metal complex to access bicyclo[4.1.0]heptenes derivatives are of great significance due to the potential application in the synthetic field. The seminal work on this topic was reported by the Blum group in 1995, where allyl propynyl ethers were converted into corresponding oxabicyclo[4.1.0]hept-4-enes using catalytic amounts of hygroscopic $\mathrm{PtCl}_{4}$ as catalyst. ${ }^{[1]}$ Shortly later Murai group reported that $O$-linked 1,6-enynes could provide 7-phenyl-3-oxabicyclo[4.1.0]hept-4-ene in $9 \%$ yield using $\mathrm{PtCl}_{2}{ }^{[2]}$ Despite poor yields at this stage, these contributions offer easy entry to bicyclic compounds by increasing molecular complexity under mild reaction conditions. Based on these discoveries, in 2001, Fürstner and co-workers systematically studied this kind of transformation utilizing a sulfonamidetethered 1,6-enynes in the presence of $\mathrm{PtCl}_{2} \cdot{ }^{[3]}$ After that, a series of metal complexes proved to be the effective catalyst in the preparation of bicyclo[4.1.0]heptenes from 1,6-enynes, for instance $\mathrm{Ir}_{,}^{[4]} \mathrm{Rh}^{[5]} \mathrm{Mn}^{[6]} \mathrm{Pt}^{[3 b, 7]}$ and $\mathrm{Au}^{[8]}$ as summarized by a series of reviews. ${ }^{[9]}$
Ruthenium complexes, as a kind of powerful tool, ${ }^{[10]}$ have been widely used to various cycloisomerization of enynes to provide complex cyclic products, ${ }^{[11]}$ such as metathesis product. Murai and co-workers have synthesized a fused tetracycles systems using dienynes through cascade cyclopropanation of ruthenium carbene intermediate. ${ }^{[12]}$ Trost group found that the cationic $\mathrm{CpRu}\left(\mathrm{CH}_{3} \mathrm{CN}\right)_{3} \mathrm{PF}_{6}$ is able to promote the intramolecular ene-type reaction of enynes, giving both five- and sixmembered cyclic adducts which can be oriented by the substitution patterns on alkene side. ${ }^{[11 b, d, 13]}$ Recently, studies concerning the enynes cycloisomerization focus mainly on the ring expansion reaction and its mechanistic exploration. ${ }^{[14]}$ However, the concise synthesis of bicyclo[4.1.0]heptenes derivatives through a ruthenium complex remains a great challenge. The single example was described by Chatani group using a well-defined cationic ruthenium dimer complex $\left[\mathrm{Ru}_{2}\left(\mathrm{O}_{2} \mathrm{CPh}\right)_{4}(\mathrm{THF})_{2}\right] \mathrm{BF}_{4}$, but only poor yields and substrates scope were observed. ${ }^{[15]}$ Herein, we reported the rutheniumcatalyzed cycloisomerization of enynes to synthesize azabicyclo [4.1.0]heptenes, and thus enriching the arsenal of ruthenium chemistry. In addition, a plausible explanation on the different reactivity of enynes bearing an internal/terminal triple bond was suggested on the basis of experimental results.

Generally, the cycloisomerization of 1,6-enynes to prepare bicyclo[4.1.0] heptenes derivatives can be achieved using highly electrophilic/alkynophilic metal complexes. ${ }^{[9 \mathrm{~d}, 11 \mathrm{cc}}$ According to deuterium labeling experiments and DFT calculation appeared in literatures, ${ }^{\left[{ }^{[9]}\right.}$ the electrophilic metal complex firstly coordinates and activates the triple bond of enynes to provide the metal $\eta^{2}$-coordination complex $\mathbf{B}$. Then the electron-rich alkene side, which severs as a nucleophilic partner, can attack the activated alkyne motif, furnishing either C via 6-endo-dig cyclization or D via 5-exo-dig cyclization process. Finally, the intramolecular rearrangement and metal elimination process afford the desired products as bicyclo[4.1.0]heptenes (F) or vinyl cyclopentenes $(E)$, respectively (Scheme 1 ).

Our preliminary study focused mainly on the theoretical analysis for the electrophilic/nucleophilic ability of ruthenium complexes since this work could greatly simplify the elementary screening experiments. According to the reported literatures, ${ }^{[16]}$ ruthenium complexes bearing a $\mathrm{Cp} / \mathrm{Cp}^{*}$ ligand prone to form ruthenacyclopentene intermediate via oxidative cyclization process, and rejecting to activate alkyne motif while preserving alkene chain. Therefore, ruthenium complexes with a $\mathrm{Cp} / \mathrm{Cp}^{*}$ ligand are firstly ruled out. Also, the ruthenium carbene complexes, for instance Grubbs catalysts, were usually em- 


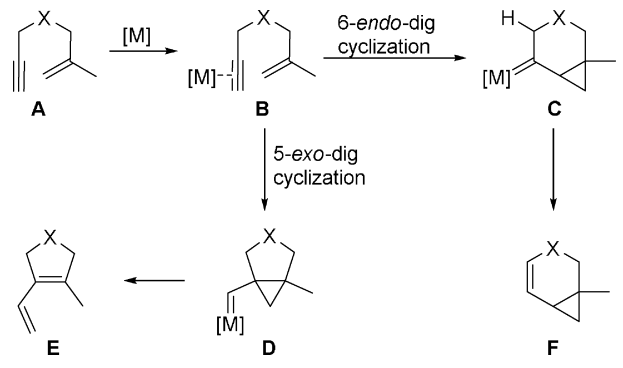

Scheme 1. Proposed reaction pathway for transition-metal-catalyzed enynes cycloisomerization.

ployed to perform the enyne metathesis reaction. ${ }^{[17]}$ Based on the above analysis, we concentrated on the use of those ruthenium complexes with strong electron-withdrawing ligands. Interestingly, the $\mathrm{RuCl}_{2}(\mathrm{DMSO})_{4}$ was capable of catalyzing the cycloisomerization of 1,6-enyne to azabicyclic[4.1.0] heptene adduct $2 \mathrm{a}$ in $18 \%$ yield while leaving unreacted $1 \mathrm{a}$ (entry 1, Table 1) under reflux conditions in DCE. Increased reaction temperature within a sealed tube failed to improve the yield of $\mathbf{2}$ a (entry 2 , Table 1 ). Inspired by the mechanism of this cycloisomerization, we then transfer our attention to the use of more electrophilic/alkynophilic metal complexes. To our delight, the commercially available ruthenium dimer $\left[\mathrm{RuCl}_{2}(\mathrm{CO})_{3}\right]_{2}$ containing strong-acceptor $\mathrm{CO}$ ligands and electron-negative chloride ligands could steadily provide the corresponding bicyclic adduct $2 \mathrm{a}$ in $71 \%$ isolated yield (entry 3 , Table 1). More interestingly, the metathesis product of enyne $\mathbf{1}$ a was not detected during this catalytic process. ${ }^{[11 a]}$ Further scope investigation indicated that the model reaction failed to react in coordinating solvent, for instance DMA and MeCN. The reason can be attributed to the coordination of nitrogen atom to

\begin{tabular}{|lllll|}
\hline Table 1. Screening of reaction conditions. ${ }^{\text {[a] }}$ & \\
& & & \\
& & & \\
\end{tabular}

ruthenium center. The best yield was obtained in 1,4-dioxane with the addition of $5 \mathrm{~mol} \%$ of $\left[\mathrm{RuCl}_{2}(\mathrm{CO})_{3}\right]_{2}$ at $90 / 110^{\circ} \mathrm{C}$. We then investigate the influence of additives on the present cycloisomerization reaction. Addition of phosphorus ligand, silver salt and CO consuming agent NMO (trimethylamine $\mathrm{N}$ oxide), had no positive influence on the cycloisomerization of 1,6-enynes because of the observed poor yields (entry 10-12, Table 1). According to the work of Chatani, cycloisomerization of enynes catalyzed by $\left[\mathrm{RuCl}_{2}(\mathrm{CO})_{3}\right]_{2}$ dimer could be well performed under an atmosphere of $\mathrm{CO}^{[11 \mathrm{a}]}$ Therefore, we then tested the effect of $\mathrm{CO}$ on our present cycloisomerization process. However, a negative effect was observed in terms of the decreased yield of $58 \%$ (entry 13, Table 1).

With the best reaction conditions in hand $(5 \mathrm{~mol} \%$ of $\left[\mathrm{RuCl}_{2}(\mathrm{CO})_{3}\right]_{2}, 1,4$-dioxane, $\left.90-110^{\circ} \mathrm{C}\right)$, the substrate scope of $\mathrm{Ru}$ (II)-mediated cycloisomerization of 1,6-eynens was thereafter examined by systematically changing the substituents on both alkynes and alkenes motifs, the results were summarized in Table 2. In most of cases, the tested 1,6-enynes are able to give their corresponding bicyclo[3.1.0]heptenes in good to excellent yields without the formation of byproducts. Interestingly, the enynes bearing methyl group at the terminus of alkynes reacted smoothly under the optimal conditions, albeit with the terminal/internal alkene (entry 1-7). Particularly, the best yield (92\%) was found when the enynes capped with an intracyclic double bond (entry 4). One of the possible reasons for the high yield can be attributed to the ring stain which was further proved by the reaction of $\mathbf{1} \mathbf{f}$ (entry 5). However, enyne bearing a cyclopropyl group on the alkyne, such as $\mathbf{1} \mathbf{i}$, afforded corresponding tricyclic product $\mathbf{2} \mathbf{i}$ in moderate yield (51\%) even with prolonged reaction time (entry 8 ). The reason can be attributed to the bulkiness of the cyclopropyl motif, which might partly prevent the coordination of ruthenium complex to alkynes, and thus slowing the reaction rate. Evidence to support this hypothesis is from the use of enyne $1 p-1 r$ that gave no desired bicyclic product under optimized reaction conditions (entry 15-17). Also, installation of an aromatic ring at the terminus of alkynes has no significant influence on the catalytic results of this cycloisomerization process for the reason of the observed high yields, albeit with electron-donating or electronwithdrawing substituent attached to the aryl group (entry 1014). However, it seems that enynes functionalized by aryl group required longer reaction time compared with those functionalized by alkyl motif. In addition, enynes $1 \mathrm{~s}$ bearing a halogen substituent at allylic position gave rise to unidentified mixture due to the decomposition of products (entry 18).

However, scope investigation found that those 1,6-enynes featuring with different tether, such as $\mathrm{O} / \mathrm{C} / \mathrm{NBn} / \mathrm{NPh}$ tether, failed to release corresponding bicyclic products (Scheme 2 ). In

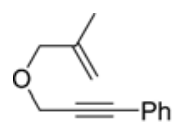

$1 \mathrm{t}$

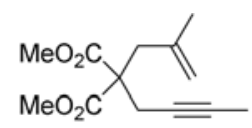

$1 \mathrm{u}$

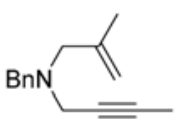

$1 v$

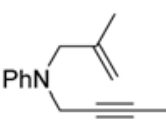

$1 w$
Scheme 2. Unsuitable enynes for $\left[\mathrm{RuCl}_{2}(\mathrm{CO})_{3}\right]_{2}$-catalyzed cycloisomerization 


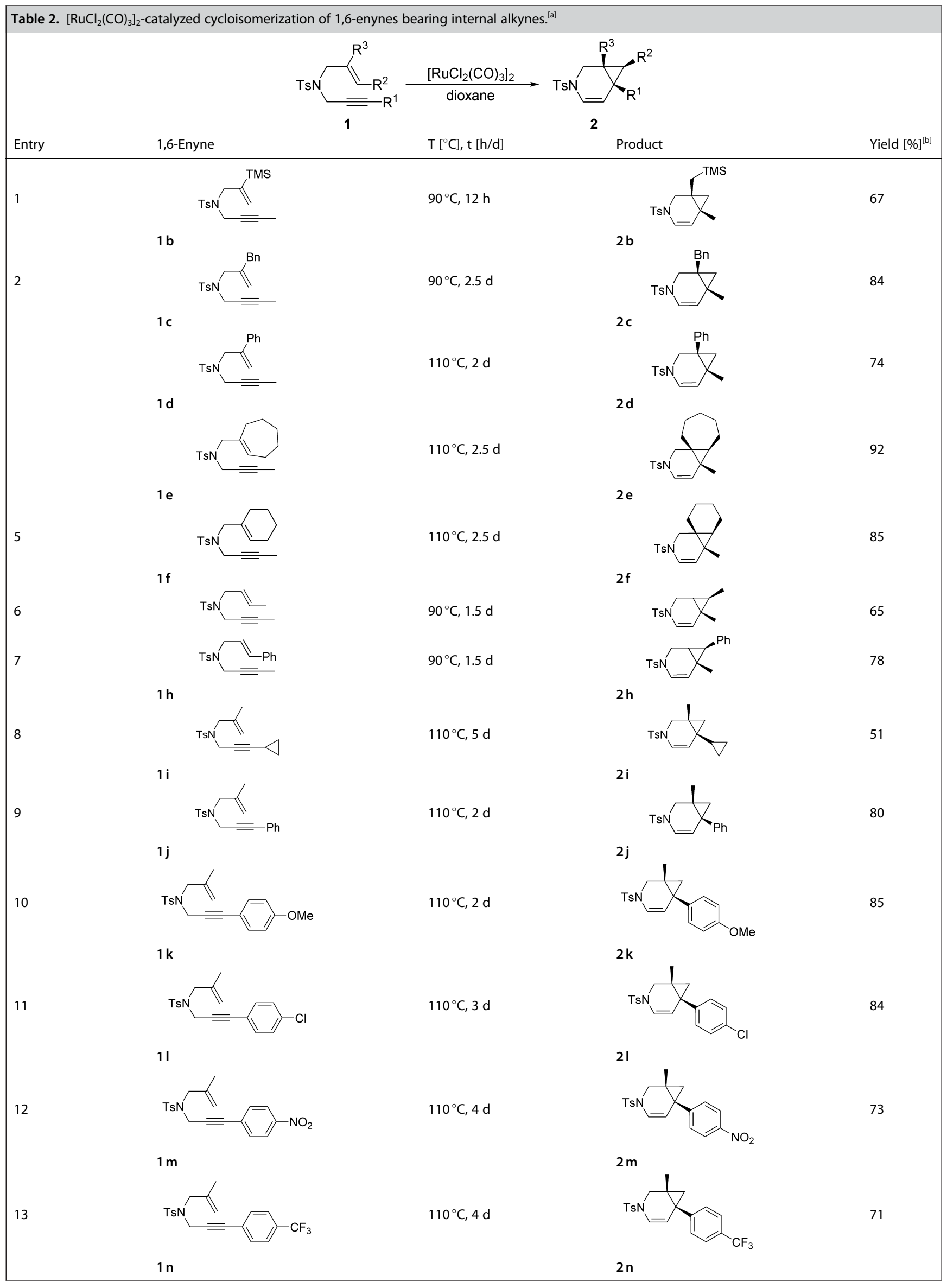




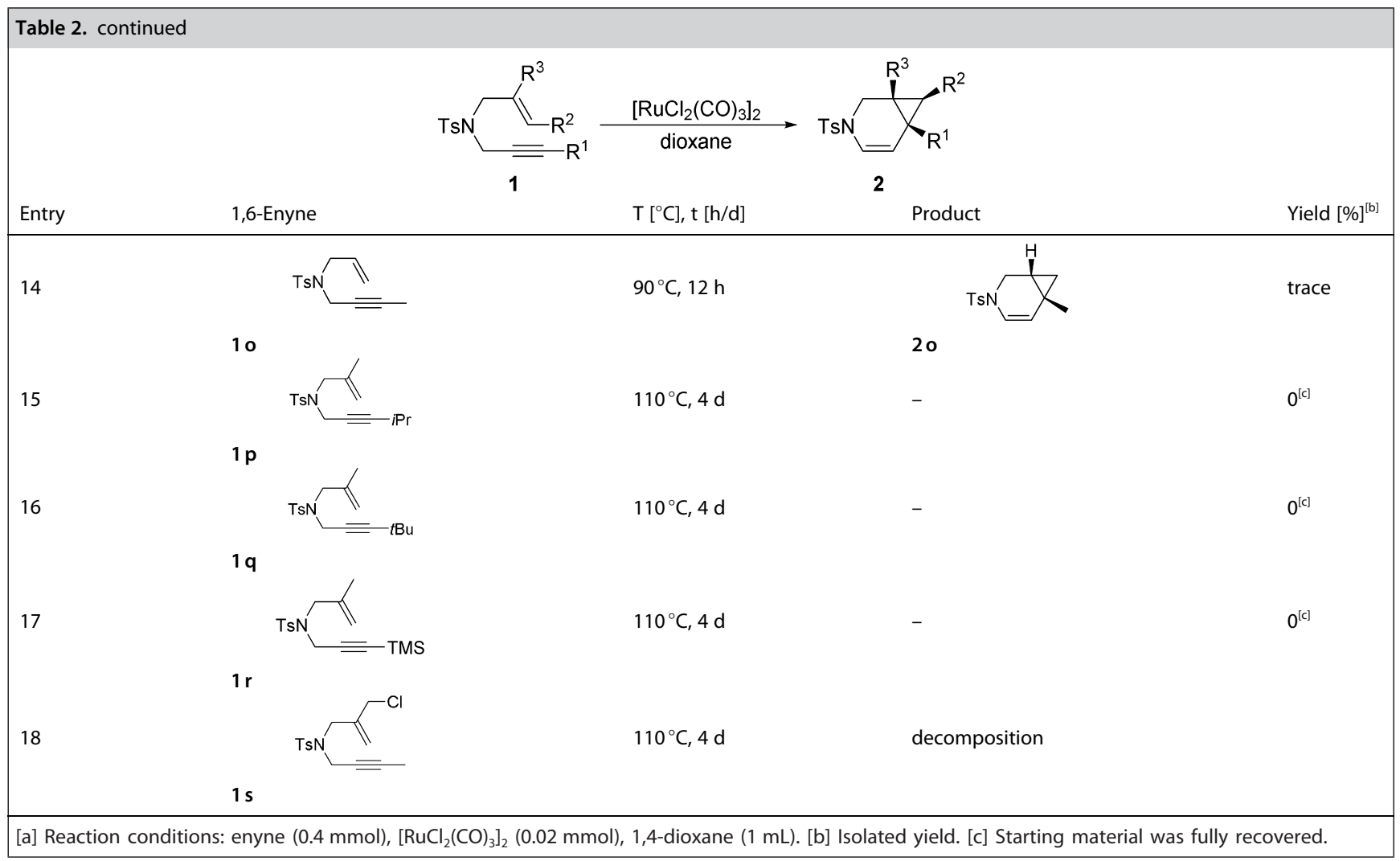

the case of $O$-linked enynes $(\mathbf{1} t)$, the starting material decomposed under the optimized reaction condition. In the case of $C$ linked enynes $(\mathbf{1} \mathbf{u})$, inseparable mixtures were observed. In addition, NBn/NPh tethered enynes $1 \mathbf{v}$ and $1 \mathbf{w}$ also give the complex mixtures probably due to the coordination effect between nitrogen atom of substrates to the ruthenium center.

Our next attention focused on the use of 1,6-enynes without a substituted group on the alkynes side. In sharp contrast to the cycloisomerization process of enynes bearing internal alkynes (Table 2), most of the tested enynes featuring with mono-substituted alkynes are prone to give both cyclic adducts azabicyclo[3.1.0]heptenes (4) and metathesis adducts (5) (Table 3). In the case of unsubstituted $3 a$, 9\% of bicyclic adduct 4 a was detected, ${ }^{[3 b]}$ and only trace amount of metathesis adduct $5 \mathrm{a}$ was observed (entry 1 ). This reason could be attributed to the fact that the mono-substituted alkene prone to undergo the oligomerization reaction under the present conditions. Substitution on either the external or internal carbon atom of alkene has no significant influence on the catalytic results since $\mathbf{4 b} \mathbf{b} \mathbf{d}$ were isolated as major and $\mathbf{5 b} \mathbf{b}-\mathbf{d}$ as minor product (entry 2-4), ${ }^{[4 b, 18]}$ respectively. However, in sharp contrast with the results of $\mathbf{3} \mathbf{a}-\mathbf{3} \mathbf{d}$, enyne $\mathbf{3 e}$ bearing an intracyclic double bond afforded metathesis product 5 e in $55 \%$ yield as major while bicyclic product 4 e was observed in $23 \%$ yield (entry 5). ${ }^{[\mathrm{bb}]}$ Notably, the configuration of double bond of $5 \mathrm{e}$ is different from the result from Fürstner. ${ }^{[3 \mathrm{~b}]}$ The reason can be attributed to the different single/double cleavage process of ruthenium carbene intermediate. ${ }^{[9 b]}$
In combination of these catalytic results (Table 2 and Table 3), it was found that enynes bearing internal alkyne only provide bicyclo[3.1.0]heptenes derivatives while enynes without a substituent at the terminus of triple bond are able to yield both bicyclo[3.1.0]heptenes and metathesis products (Table 2 VS Table 3). Also, it seems that the enynes bearing aryl group on the terminal position of alkyne required relatively longer reaction times compared with those bearing alkyl group (Table 2). These phenomenons can be attributed to the agostic effect between the ruthenium center and $\mathrm{C}-\mathrm{H}$ bond as outlined in Scheme 3 (intermediate $\mathbf{H}$ and I). ${ }^{\left[{ }^{[9]}\right.}$ Due to the existence of agostic interaction, the formation of intermediate $\mathbf{H}$ and $\mathbf{I}$ are preferentially favored with respect to ruthenium carbene $\mathbf{G}$, and thus giving bicyclic adducts as sole products. As to the longer reaction time of aryl substituted enynes, the reason could be ascribed to the conjugation effect between alkyne and aromatic group of ruthenium intermediate $\mathbf{B}$, which lowered the reaction rate from $B$ to $I$.

In conclusion, a cycloisomerization of $\mathrm{N}$-linked 1,6-enynes was achieved in the presence of commercially available

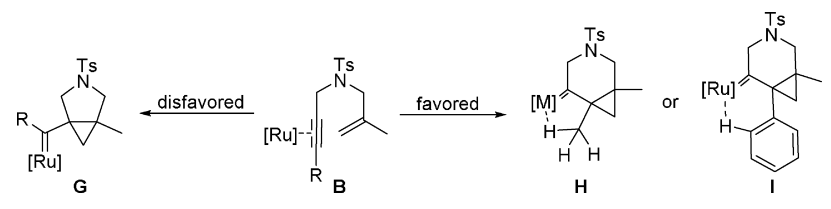

Scheme 3. Proposed reaction intermediate in $\mathrm{Ru}(\mathrm{II})$-catalyzed cycloisomerization of enynes. 


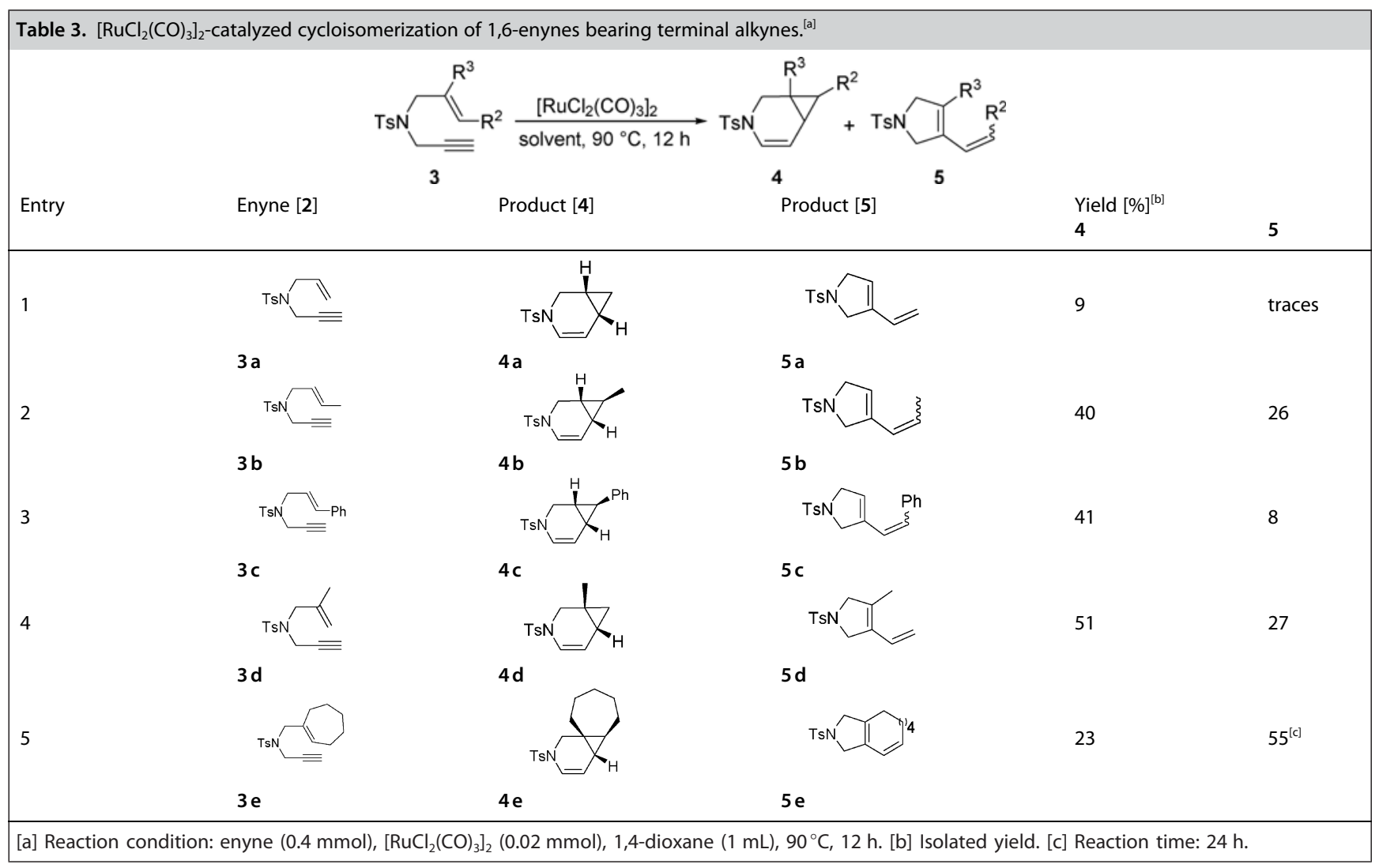

ruthenium complex $\left[\mathrm{RuCl}_{2}(\mathrm{CO})_{3}\right]_{2}$, affording a series of functionalized azabicyclo[4.1.0]heptenes derivatives in good to excellent yields. Scope investigation indicated substituents on either double bond or triple bond of enynes can be well tolerated in this catalytic process. In combination with an agostic effect and conjugation effect, the competitive formation of both bicyclic adducts and metathesis products could be well rationalized. This protocol has successfully extended this kind of cycloisomerization to a ruthenium complex, and thus enriches the family of ruthenium chemistry. A study concerning the intermolecular reaction catalyzed by $\left[\mathrm{RuCl}_{2}(\mathrm{CO})_{3}\right]_{2}$ is underway in our lab.
[1] J. Blum, H. Beer-Kraft, Y. Badrieh, J. Org. Chem. 1995, 60, 5567-5569.

[2] N. Chatani, N. Furukawa, H. Sakurai, S. Murai, Organometallics 1996, 15, 901-903.

[3] a) A. Fürstner, H. Szillat, F. Stelzer, J. Am. Chem. Soc. 2000, 122, 67856786; b) A. Fürstner, F. Stelzer, H. Szillat, J. Am. Chem. Soc. 2001, 123, 11863-11869.

[4] a) T. Shibata, Y. Kobayashi, S. Maekawa, N. Toshida, K. Takagi, Tetrahedron 2005, 61, 9018-9024; b) E. Benedetti, A. Simonneau, A. Hours, H. Amouri, A. Penoni, G. Palmisano, M. Malacria, J.-P. Goddard, L. Fensterbank, Adv. Synth. Catal. 2011, 353, 1908-1912; c) M. Dieckmann, Y.-S. Jang, N. Cramer, Angew. Chem. Int. Ed. 2015, 54, 12149-12152; Angew. Chem. 2015, 127, 12317-12320; d) M. Barbazanges, M. Augé, J. Moussa, H. Amouri, C. Aubert, C. Desmarets, L. Fensterbank, V. Gandon, M. Malacria, C. Ollivier, Chem. Eur. J. 2011, 17, 13789-13794.

[5] a) K. Ota, S. I. Lee, J.-M. Tang, M. Takachi, H. Nakai, T. Morimoto, H. Sakurai, K. Kataoka, N. Chatani, J. Am. Chem. Soc. 2009, 131, 1520315211 ; b) S. Y. Kim, Y. K. Chung, J. Org. Chem. 2010, 75, 1281-1284; c) T. Nishimura, Y. Maeda, T. Hayashi, Org. Lett. 2011, 13, 3674-3677; d) T. Nishimura, Y. Takiguchi, Y. Maeda, T. Hayashi, Adv. Synth. Catal. 2013, 355, 1374-1382; e) K. Masutomi, K. Noguchi, K. Tanaka, J. Am. Chem. Soc. 2014, 136, 7627-7630.

[6] T. Ozawa, T. Kurahashi, S. Matsubara, Org. Lett. 2012, 14, 3008-3011.

[7] a) J. Marco-Contelles, N. Arroyo, S. Anjum, E. Mainetti, N. Marion, K. Cariou, G. Lemière, V. Mouriès, L. Fensterbank, M. Malacria, Eur. J. Org. Chem. 2006, 2006, 4618-4633; b) D. Brissy, M. Skander, H. Jullien, P. Retailleau, A. Marinetti, Org. Lett. 2009, 11, 2137-2139; c) D. Brissy, M. Skander, P. Retailleau, G. Frison, A. Marinetti, Organometallics 2009, 28, 140-151; d) Z. Ni, L. Giordano, A. Tenaglia, Chem. Eur. J. 2014, 20, $11703-11706$.

[8] a) A. Pradal, C.-M. Chao, P. Y. Toullec, V. Michelet, Beilstein J. Org. Chem. 2011, 7, 1021-1029; b) C. Ferrer, M. Raducan, C. Nevado, C. K. Claverie, A. M. Echavarren, Tetrahedron 2007, 63, 6306-6316; c) P. Pérez-Galán, E. Herrero-Gómez, D. T. Hog, N. J. A. Martin, F. Maseras, A. M. Echavarren, Chem. Sci. 2011, 2, 141-149; d) W. Wang, J. Yang, F. Wang, M. Shi, Organometallics 2011, 30, 3859-3869; e) H. Teller, M. Corbet, L. Mantilli, G. Gopakumar, R. Goddard, W. Thiel, A. Fürstner, J. Am. Chem. Soc. 2012, 134, 15331-15342; f) D.-H. Zhang, Y. Wei, M. Shi, Chem. Eur. J. 2012, 18, 7026-7029; g) K. Yavari, P. Aillard, Y. Zhang, F. Nuter, P. Retailleau, A. 
Voituriez, A. Marinetti, Angew. Chem. Int. Ed. 2013, 53, 861-865; h) F. Schröder, C. Tugny, E. Salanouve, H. Clavier, L. Giordano, D. Moraleda, Y Gimbert, V. Mouriès-Mansuy, J.-P. Goddard, L. Fensterbank, Organometallics 2014, 33, 4051-4056; i) K. Yavari, P. Aillard, Y. Zhang, F. Nuter P. Retailleau, A. Voituriez, A. Marinetti, Angew. Chem. Int. Ed. 2014, 53, 861-865; Angew. Chem. 2014, 126, 880-884.

[9] a) C. Bruneau, Angew. Chem. Int. Ed. 2005, 44, 2328-2334; Angew. Chem. 2005, 117, 2380-2386; b) A. Fürstner, Chem. Soc. Rev. 2009, 38, 32083221 ; c) E. Soriano, J. Marco-Contelles, Acc. Chem. Res. 2009, 42, 1026 1036; d) P. Y. Toullec, V. Michelet, in Computational Mechanisms of Au and Pt Catalyzed Reactions (Eds.: E. Soriano, J. Marco-Contelles), Springer Berlin Heidelberg, Berlin, Heidelberg, 2011, pp. 31-80; e) Z. Liming, S. Jianwei, Adv. Synth. Catal. 2006, 348, 2271-2296.

[10] a) B. Alcaide, P. Almendros, A. Luna, Chem. Rev. 2009, 109, 3817-3858, b) P. B. Arockiam, C. Bruneau, P. H. Dixneuf, Chem. Rev. 2012, 112, 58795918; c) A. M. Lozano-Vila, S. Monsaert, A. Bajek, F. Verpoort, Chem. Rev. 2010, 110, 4865-4909; d) T. Naota, H. Takaya, S.-I. Murahashi, Chem. Rev. 1998, 98, 2599-2660; e) C. Samojłowicz, M. Bieniek, K. Grela, Chem. Rev. 2009, 109, 3708-3742; f) D. Wang, D. Astruc, Chem. Rev. 2015, 115, 6621-6686; g) S.-I. Murahashi, ed. "Ruthenium in Organic Synthesis", Wiley-VCH, 2004; h) C. Bruneau, P. H. Dixneuf, eds. "Ruthenium Catalysts and Fine Chemistry", Top. Organomet. Chem. 11, Springer, 2004.

[11] a) N. Chatani, T. Morimoto, T. Muto, S. Murai, J. Am. Chem. Soc. 1994, 116, 6049-6050; b) B. M. Trost, F. D. Toste, J. Am. Chem. Soc. 2000, 122, 714-715; c) C. Aubert, O. Buisine, M. Malacria, Chem. Rev. 2002, 102, 813-834; d) B. M. Trost, J. P. Surivet, F. D. Toste, J. Am. Chem. Soc. 2004 126, 15592-15602; e) B. M. Trost, M. U. Frederiksen, M. T. Rudd, Angew. Chem. Int. Ed. 2005, 44, 6630-6666; Angew. Chem. 2005, 117, 67886825 ; f) J. W. Faller, P. P. Fontaine, J. Organomet. Chem. 2006, 691, 1912 1918; g) S. T. Diver, Coord. Chem. Rev. 2007, 251, 671-701; h) F. Monnier C. Vovard-Le Bray, D. Castillo, V. Aubert, S. Dérien, P. H. Dixneuf, L. Toupet, A. lenco, C. Mealli, J. Am. Chem. Soc. 2007, 129, 6037-6049; i) C. P. Chung, C.-C. Chen, Y.-C. Lin, Y.-H. Liu, Y. Wang, J. Am. Chem. Soc 2009, 131, 18366-18375; j) S. I. Lee, N. Chatani, Chem. Commun. 2009,
371-384; k) N. Saito, D. Tanaka, M. Mori, Y. Sato, Chem. Rec. 2011, 11, 186-198; I) Y. Zhou, Y. Zhang, J. Wang, Org. Biomol. Chem. 2016, 14, 6638-6650..

[12] N. Chatani, K. Kataoka, S. Murai, N. Furukawa, Y. Seki, J. Am. Chem. Soc 1998, 120, 9104-9105.

[13] a) B. M. Trost, F.D. Toste, J. Am. Chem. Soc. 2002, 124, 5025-5036; b) B. M. Trost, J.-P. Surivet, F. D. Toste, J. Am. Chem. Soc. 2004, 126, 15592-15602.

[14] a) B. M. Trost, Acc. Chem. Res. 2002, 35, 695-705; b) B. M. Trost, H. C. Shen, D. B. Horne, E. D. Toste, B. G. Steinmetz, C. Koradin, Chem. Eur. J. 2005, 11, 2577-2590; c) B. M. Trost, Y. Hu, D. B. Horne, J. Am. Chem. Soc. 2007, 129, 11781-11790; d) X. Hong, B. M. Trost, K. N. Houk, J. Am. Chem. Soc. 2013, 135, 6588-6600.

[15] T. Nakae, T. Yasunaga, M. Kamiya, Y. Fukumoto, N. Chatani, Chem. Lett. 2013, 42, 1565-1567.

[16] Y. Yamamoto, Tetrahedron Lett. 2017, 58, 3787-3794.

[17] a) M. Mori, N. Sakakibara, A. Kinoshita, J. Org. Chem. 1998, 63, 60826083 ; b) M. Bieniek, R. Bujok, M. Cabaj, N. Lugan, G. Lavigne, D. Arlt, K. Grela, J. Am. Chem. Soc. 2006, 128, 13652-13653; c) R. Castarlenas, C. Vovard, C. Fischmeister, P. H. Dixneuf, J. Am. Chem. Soc. 2006, 128 , 4079-4089; d) Q. Yang, H. Alper, W.-J. Xiao, Org. Lett. 2007, 9, 769-771; e) F. Boeda, H. Clavier, M. Jordaan, W. H. Meyer, S. P. Nolan, J. Org. Chem. 2008, 73, 259-263; f) D. Rix, F. Caijo, I. Laurent, F. Boeda, H. Clavier, S. P. Nolan, M. Mauduit, J. Org. Chem. 2008, 73, 4225-4228.

[18] a) H. Clavier, C. A. Urbina-Blanco, S. P. Nolan, Organometallics 2009, 28 2848-2854; b) D. N. Prada Gori, C. Permingeat Squizatto, P. G. Cornier, C. M. L. Delpiccolo, J. Org. Chem. 2018, 83, 12798-12805.

[19] S. J. La Placa, J. A. Ibers, Inorg. Chem. 1965, 4, 778-783. 